\title{
Health, biodiversity, and natural resource use on the Amazon frontier: an ecosystem approach
}

\author{
Saúde, biodiversidade e uso de recursos \\ naturais na fronteira da Amazônia: \\ uma abordagem ecossistêmica
}

Tamsyn P. Murray 1

José Sánchez-Choy 1

1 Centro Internacional de Agricultura Tropical, Eco-Regional Centre. Km 4,2 Federico Basadre A.P. 558, Pucallpa, Peru. t.murray@cgiar.org

\begin{abstract}
This study aims to improve the health of rural Amazonian communities through the development and application of a participatory ecosystem approach to human health assessment. In the study area marked seasonal fluctuations dictate food availability, water quality and disease outbreak. Determining the causal linkages between ecosystem variables, resource use and health required a variety of forms of inquiry at multiple scales with local participation. Landscape spatial mapping of resource use demonstrated the diversity of the ecological resources upon which communities depend. Household surveys detailed family and individual consumption and production patterns. Anthropometric measurements, parasite loading, water quality and anemia levels were used as indicators of health status. This was complemented with an ethnographic and participatory health assessment that provided the foundation for developing community action plans addressing health issues. Discussion is focused on three attributes of an ecosystem approach; (a) methodological pluralism, (b) cross-scale interactions and (c) participatory action research.
\end{abstract}

Key words Human Ecology; Amazonian Ecosystem; Rural Health; Anthropometry; Nutrition

Resumo O estudo visa melhorar a saúde das comunidades rurais amazônicas mediante o desenvolvimento e a aplicação de abordagem ecossistêmica participante na avaliação da saúde humana. Na área estudada, oscilações sazonais definem a disponibilidade de alimentos, a qualidade da água e a incidência de doenças. A determinação dos elos causais entre variáveis ecossistêmicas, uso de recursos e saúde exigiu uma gama de formas de investigação, em múltiplas escalas, com participação local. O mapeamento espacial da paisagem quanto ao uso de recursos mostrou a diversidade dos recursos ecológicos de que as comunidades dependem. Inquéritos domiciliares detalharam padrões de consumo e produção familiares e individuais. Medidas antropométricas, carga parasitária, qualidade da água e níveis de anemia foram empregados como indicadores do estado de saúde individual e coletivo. Tais marcadores foram complementados com avaliação etnográfica e participante sobre saúde, o que criou a base para desenvolver planos de ação comunitária para lidar com questões de saúde. A discussão enfoca três atributos de abordagem ecossistêmica: (a) pluralismo metodológico, (b) interações transversais, em termos de escala e (c) pesquisa-ação participante.

Palavras-chave Ecologia Humana; Ecossistema Amazônico; Saúde Rural; Antropometria; Nutrição 


\section{Introduction}

Enhancing the overall health and sustainability of the ecosystem rests in our ability to understand the interactions among natural resource use, land use change, and human health. An ecosystem approach focuses on the relationships between such components, identifying the key causal linkages and feedback that determine system health. In the Amazon lowlands, understanding how the adaptive livelihood strategies of frontier communities relate to and are synchronized with the constantly changing floodplain and upland forests, provides insight into the determinants of food security, nutritional status, and human health. The hydrological cycle and the resulting 8-15 meter change in river levels, dictate migratory patterns of fish and wild animals, agricultural production cycles, and seasonal availability of forest foods. In addition the consequent habitat changes affect vector prevalence, disease outbreak, and periodicity. This study developed a methodology for assessing health in the context of this complex ecosystem, attempting to differentiate those factors most significant in determining human health.

The research site comprises the frontier region of Ucayali, the Eastern-most province of the Peruvian Amazon. This area and the surrounding upper rainforests are of great biological significance, containing $23 \%$ and $44 \%$ of known tropical plant and bird diversity in the Neotropics (IUCN, 1996). Despite the natural diversity and fecundity of the setting, rural communities face a range of nutritional and health problems. Chronic malnutrition affects $47 \%$ of rural children below age five (INEI, 1997a), anemia and vitamin A deficiencies are widespread, and cases of malaria, dengue fever, and persistent diarrhea continue to rise (Dirección Regional de Salud, 1997). Health research has demonstrated the importance of nutrition to child development and human health (Pelletier et al., 1993; Bailey et al., 1998).

In the study area, agricultural production, fishing, and wild food extraction provide the main sources of food consumed. Access to health care is restricted as most medical professionals are concentrated in the urban areas (INEI, 1997b) and inadequate infrastructure and seasonal flooding isolate frontier communities. Nutritional status and human health is therefore largely dependent on the family's ability to ensure sufficient nutrient intake through a diversity of production activities, to reduce its own susceptibility to disease through environmental management and hygiene, and to provide treatment with wild and domesticated medicinal plants.

Exploitation of resources in the surrounding ecosystems results in diverse seasonal combinations of farming, fishing, logging, and hunting and gathering activities. Differences exist in terms of the combinations of resource use activities both on and off the farm, the diversity of such resource uses, and the proportion of income-generating versus subsistence activities. Such differences are closely linked to the farm's location with respect to rivers, roads, markets, and available natural resources. Within such populations, the relationship between household production, income level, and nutrition is complex and poorly understood (Leonard et al., 1993). How such different resource strategies affect the health of the household is not yet known. Although subsistence activities directly affect nutrition and food security of the household, increases in income generation are not necessarily equated with improved nutritional levels. Although the perception a decade ago was that the most effective means of reducing malnutrition was the general process of development, with it concomitant income increases (World Bank, 1980), the consensus view now is that calorie consumption is much less responsive to income increases than originally thought (Behrman \& Deolalikar, 1987; Behrman, 1995). Increases in production and income that result from improved technologies and agricultural intensification may, but do not necessarily, lead to changes in health and nutritional status (von Braun \& Kennedy, 1994). In fact several recent studies have shown decreased nutrition levels associated with cash-cropping even though income levels rose (Akanji, 1998; Kinsey, 1998; Nowak, 1998). Knowing whether nutrition and earning levels are related has important implications for agricultural and technology development for this frontier region.

\section{Research goals and methods}

This study aims to improve the health and nutrition of rural communities through the development of a participatory ecosystem approach to human health assessment that provides insight into the causal linkages between health, biodiversity, and natural resource use. The study includes both research and development components. It was designed to ensure that the research findings guided community action plans and the development of health and agricultural policy. From the outset, the Ministry of 
Health, leaders of local organizations, and the communities themselves were involved in the design, implementation, and analysis of the research. As the third and last phase of field research is yet to be completed, this paper focuses on the methodological aspects of the study, providing insight into the strengths of the ecosystem approach as it was applied in this Amazon region.

\section{Household surveys and field testing}

To begin, the causal linkages between the multiple resource use systems of the different communities and human health were investigated. First, this involved characterization and assessment of the livelihood systems of floodplain and upland communities with respect to: (a) diversity of food and income sources; (b) agricultural diversity and biodiversity of wild foods gathered from surrounding forests; and (c) the contribution of different land uses (fishing, farming, hunting and gathering, logging) to dietary quality and food security. Second, assessment of the level of household food security and the nutritional status of individual men, women, and children, with emphasis on seasonal changes in nutrient intake and deficiencies of micronutrients (iron, zinc, calcium, vitamin A, B, and C). Third, characterization of the patterns of maternal and infant mortality, general morbidity, and disease periodicity of men, women, and children. Fourth, testing the quality of water used for drinking and bathing. Coliform counts, $\mathrm{pH}$, and turbidity were used as indicators of water quality. And fifth, determining the prevalence and incidence of parasitic infections in children and hemoglobin levels in women and children. Stool samples were analyzed in the field with a microscope, and the WHO HemoCue Color Scale was used for testing hemoglobin levels. Table 1 identifies all study variables, specific methods, and frequency and period of recall.

From the above data, the significant correlates of health and nutritional status and the causal linkages between natural resource use, biodiversity, and health are being determined through multivariate analyses and modeling. The following hypotheses are being evaluated: (a) a more productive ecosystem results in higher nutritional and health status; (b) greater diversity of food sources, from the farm and surrounding forests, results in higher nutritional status; (c) nutritional and health status will vary between native and colonist communities due to differences in culture and local knowledge of biodiversity and ecological re- sources; (d) the shift from more subsistenceoriented to commercial production systems does not necessarily result in an increase in health and nutritional status; (e) the shift to commercial production affects the role of women in the household, their time allocation, and involvement in health and nutrition decisions; and (f) nutritional and health status will vary throughout the year due to seasonal differences in nutrient intake and water quality.

All the above surveys and field tests were conducted in eight different communities in the Ucayali region. From a methodological perspective, it was important to include sites that would differentiate factors affecting health. To capture the region's heterogeneity, the following criteria guided the selection process; (a) ecosystem type (floodplain versus upland forests), (b) ethnicity (native versus colonist), (c) access to markets and involvement in market economy, (d) time of settlement (early versus old frontier), and (e) dominant land use strategy (slash and burn agriculture, fishing, cattle ranching, and oil palm plantations). Within each community, between 35 and 50 families were involved in the study. In total 345 families and 1,725 individuals participated.

Although average precipitation in Ucayali ranges between $2,000-3,000 \mathrm{~mm}$, there is a marked rainy season. Rains start in September/October, and continue until March/April. During this time, rivers and lakes rise up to fifteen meters, dramatically changing the landscape. Agricultural production as well as the availability of fish, animals, and foods gathered from the forests are tied to this hydrological cycle. In order to capture the effects of these seasonal fluctuations on diet and disease, three time periods were selected at which time the key study variables were measured repeatedly; (a) June/July 1999 (dry season), (b) October/ November 1999 (start of the rains), and (c) February/March 2000 (wet season). With these three time periods and sets of data, the cycles in food availability, disease outbreaks and periodicity, and nutrient intake are being analyzed. This identifies not only the critical periods when food is scarce and disease more prevalent, but also the interaction between such cycles. Efforts can therefore be focused on these key periods when health problems are most severe and intervention will have the greatest impact. 
Table 1

Data collection for the household surveys and field tests.

\begin{tabular}{|c|c|c|c|c|c|c|c|}
\hline Level & Indicators & Variables & $\begin{array}{l}\text { Round } 1 \\
\text { June- } \\
\text { July } 99\end{array}$ & $\begin{array}{l}\text { Round } 2 \\
\text { Oct- } \\
\text { Nov } 99\end{array}$ & $\begin{array}{l}\text { Round } 3 \\
\text { March- } \\
\text { April } 00\end{array}$ & Methods & $\begin{array}{l}\text { Frequency of collection/ } \\
\text { Period of recall }\end{array}$ \\
\hline Landscape & $\begin{array}{l}\text { Ecosystem } \\
\text { productivity }\end{array}$ & Soil fertility & & $x$ & $x$ & $\begin{array}{l}\text { Soil tests } \\
\text { Existing information }\end{array}$ & Once at each site \\
\hline \multirow[t]{4}{*}{ Community } & Access to food & Food prices & $x$ & $x$ & $x$ & Observe & $3 x$ \\
\hline & & Food availability & $x$ & $x$ & $\mathrm{X}$ & Observe & $3 x$ \\
\hline & $\begin{array}{l}\text { Access to } \\
\text { education }\end{array}$ & $\begin{array}{l}\text { Education facilities } \\
\text { available }\end{array}$ & $x$ & $\mathrm{x}$ & $x$ & $\begin{array}{l}\text { Interview with } \\
\text { leaders \& teachers }\end{array}$ & $\begin{array}{l}\text { Once on initial visit/Include } \\
\text { changes during study }\end{array}$ \\
\hline & $\begin{array}{l}\text { Access to health } \\
\text { services }\end{array}$ & $\begin{array}{l}\text { Health services } \\
\text { available }\end{array}$ & $x$ & $x$ & $x$ & $\begin{array}{l}\text { Interview with } \\
\text { health worker }\end{array}$ & Same as above \\
\hline \multirow[t]{11}{*}{ Household } & $\begin{array}{l}\text { Socio-economic } \\
\text { status }\end{array}$ & Wealth index & & $x$ & & Recall & Once \\
\hline & & $\begin{array}{l}\text { Non-food } \\
\text { expenditures }\end{array}$ & & & $x$ & Recall & $\begin{array}{l}\text { Once. Recall period varies } \\
\text { with item }\end{array}$ \\
\hline & Nutritional status & $\begin{array}{l}\text { Energy and } \\
\text { nutrient intake }\end{array}$ & $x$ & $x$ & $x$ & 24 hour recall & $3 X$ for prior 24 hours \\
\hline & Food Security & & & & & & \\
\hline & Dietary Quality & Nutrient intake & $x$ & $x$ & $x$ & Food frequency recall & $3 X$ for prior 7 days \\
\hline & Dietary diversity & Food sources & $x$ & $x$ & $x$ & Recall & $3 X$ for prior 24 hours \\
\hline & $\begin{array}{l}\text { Income level; } \\
\text { diversity }\end{array}$ & Income by source & $x$ & $x$ & $x$ & Recall & $\begin{array}{l}3 \mathrm{X} \text {, round } 1 \text { for prior } \\
\text { growing season, round } 2 \\
\text { and } 3 \text { for period b/w visits. }\end{array}$ \\
\hline & $\begin{array}{l}\text { Production levels; } \\
\text { diversity }\end{array}$ & $\begin{array}{l}\text { Production and } \\
\text { extraction outputs }\end{array}$ & $x$ & $\mathrm{X}$ & $x$ & Recall & Same as above \\
\hline & Food security & Crop storage & & $x$ & $x$ & Recall & $\begin{array}{l}2 X \text {, report what is in storage } \\
\text { at time of visit }\end{array}$ \\
\hline & $\begin{array}{l}\text { Water access; } \\
\text { contamination }\end{array}$ & Water Quality & $\mathrm{X}$ & $\mathrm{x}$ & $x$ & $\begin{array}{l}\text { Water samples } \\
\text { Escherichia coli, } \\
\text { pH \& turbidity }\end{array}$ & Three times \\
\hline & $\begin{array}{l}\text { Environmental } \\
\text { health }\end{array}$ & Hygiene Practices & & $x$ & & Recall & Once \\
\hline
\end{tabular}

(continued)

The ethnographic and participatory health assessment

In the periods between the household surveys, measures of individual and community health were developed through participatory action research. These measures enabled the communities to be directly involved in the study and to better understand the factors affecting their nutritional and health status. During this more extended period spent in the communities, an ethnographic study was carried out at each site, exploring how local beliefs, knowledge, and decision-making processes affect the selection of foods and the treatment of illness.
In addition, a participatory assessment of the health and nutrition helped to identify the community's health priorities and through this develop local definitions and indicators of health. Several methods were drawn from Participatory Action Research (PAR), Participatory Rural Appraisal (PRA), and Rapid Assessment Procedures (RAP). They included: seasonal calendars of resource use; food availability and health; community and landscape mapping; health transects; timeline; pile-sorting; life histories; focus groups; case histories; decision models; key informant interviews; body and sexuality mapping; and wealth ranking. The participatory nature of these data collection 


\begin{tabular}{|c|c|c|c|c|c|c|c|}
\hline Level & Indicators & Variables & $\begin{array}{l}\text { Round } 1 \\
\text { June- } \\
\text { July } 99\end{array}$ & $\begin{array}{l}\text { Round } 2 \\
\text { Oct- } \\
\text { Nov } 99\end{array}$ & $\begin{array}{l}\text { Round } 3 \\
\text { March- } \\
\text { April } 00\end{array}$ & Methods & $\begin{array}{l}\text { Frequency of collection/ } \\
\text { Period of recall }\end{array}$ \\
\hline \multirow[t]{9}{*}{ Child } & $\begin{array}{l}\text { Growth and } \\
\text { development }\end{array}$ & $\begin{array}{l}\text { Anthropometric } \\
\text { measurements }\end{array}$ & $x$ & $x$ & $x$ & Actual measurement & Three times \\
\hline & Nutritional status & $\begin{array}{l}\text { Energy and } \\
\text { nutrient intake }\end{array}$ & $x$ & $x$ & $x$ & Recall & $3 X$ for prior 24 hours \\
\hline & Health status & Breastfeeding history & $x$ & & & Recall by mother & Once on initial visit \\
\hline & & $\begin{array}{l}\text { Diarrhea incidence } \\
\text { \& patterns }\end{array}$ & $x$ & $x$ & $x$ & Recall by mother & $\begin{array}{l}3 \mathrm{X} \text {, round } 1 \text { for prior } 6 \\
\text { months, round } 2 \text { and } 3 \text { for } \\
\text { period between visits }\end{array}$ \\
\hline & & $\begin{array}{l}\text { Incidence and } \\
\text { patterns of } \\
\text { respiratory infections }\end{array}$ & $x$ & $x$ & $x$ & Recall by mother & Same as above \\
\hline & & Morbidity patterns & & $x$ & $x$ & Recall by mother & $\begin{array}{l}\text { Once for prior six months } \\
\text { and whole life, last round } \\
\text { for period between surveys }\end{array}$ \\
\hline & & Mortality & & $x$ & & Recall by mother & $\begin{array}{l}\text { Once, deaths during survey } \\
\text { period are recorded }\end{array}$ \\
\hline & & Iron status & & $x$ & $x$ & $\begin{array}{l}\text { Measurement } \\
\text { of hemoglobin }\end{array}$ & Twice (WHO Color Scale) \\
\hline & & Parasitic infection & & $x$ & $x$ & Stool samples & Twice \\
\hline \multirow[t]{4}{*}{ Women } & Nutritional status & $\begin{array}{l}\text { Energy and } \\
\text { nutrient intake }\end{array}$ & $x$ & $x$ & $x$ & Recall & $3 X$ for prior 24 hours \\
\hline & Female fertility & Reproductive history & $x$ & & & Recall & Once on initial visit \\
\hline & Health status & Morbidity patterns & & $x$ & & Recall & $\begin{array}{l}\text { Once for prior six months } \\
\text { and whole life, last round } \\
\text { for period between surveys }\end{array}$ \\
\hline & Labor demand & Time allocation & $x$ & $x$ & $x$ & Recall & $3 X$ for prior 24 hours \\
\hline \multirow[t]{3}{*}{ Men } & Nutritional status & $\begin{array}{l}\text { Energy and } \\
\text { nutrient intake }\end{array}$ & $x$ & $x$ & $x$ & Recall & $3 X$ for prior 24 hours \\
\hline & Health status & Morbidity patterns & & $x$ & & Recall & Same as women \\
\hline & Labor demand & Time allocation & $\mathrm{x}$ & $\mathrm{x}$ & $x$ & Recall & Same as above \\
\hline
\end{tabular}

techniques promoted open dialogue among community members and started the process of building a trusting environment in which the community could entertain organized and coordinated planning and action. Table 2 outlines in more detail the methods used.

\section{Spatial mapping of resource use}

At the landscape level, it was evident that the area from which the community draws both food and non-food resources is large and diverse. On a number of occasions throughout the year, people travel large distances to exploit fish and forest resources available only at certain times. Geographic Positioning System (GPS) coordinates were taken in the areas where people hunted, logged, fished, and gathered wild plants, fruits, and seeds. Spatially mapping this area provides insight into the diversity of ecosystems/biota/biotypes upon which people depend as well as the capacity of the forest in supporting the local population. The variation in the range of ecological resources surrounding each community highlighted their relative importance for the nutrition and welfare of the community. For example, inland lakes supply communities with fish all year round and palm forests ensure a food supply for wild animals and therefore an alternate source of protein-rich food. 
Table 2

Data collection for spatial mapping and ethnographic and participatory health assessment.

\begin{tabular}{|c|c|c|c|c|c|c|}
\hline Level & Variables & $\begin{array}{l}\text { Summer } \\
\text { Aug/Sept } \\
1999\end{array}$ & $\begin{array}{l}\text { Winter } \\
\text { Jan/Feb } \\
2000\end{array}$ & Methods & $\begin{array}{l}\text { Participants } \\
{ }^{\star} \text { number in brackets } \\
\text { indicates the \# of groups }\end{array}$ & $\begin{array}{l}\text { Freq. of collection/ } \\
\text { period of recall }\end{array}$ \\
\hline \multirow[t]{2}{*}{ Landscape } & $\begin{array}{l}\text { Spatial mapping of } \\
\text { ecological diversity; lakes, } \\
\text { swamps, forests, rivers, } \\
\text { palm forests etc. }\end{array}$ & $x$ & $x$ & GPS/GIS & $\begin{array}{l}\text { Farmers/fishermen/ } \\
\text { hunters and gatherers }\end{array}$ & Twice, dry and wet season \\
\hline & $\begin{array}{l}\text { Spatial mapping of } \\
\text { resource use activities; } \\
\text { farming, fishing, hunting, } \\
\text { gathering and logging }\end{array}$ & $x$ & $x$ & GPS/GIS & $\begin{array}{l}\text { Farmers/fishermen/ } \\
\text { hunters and gatherers }\end{array}$ & Same as above \\
\hline \multirow[t]{6}{*}{ Community } & Sources of information & $x$ & & $\begin{array}{l}\text { Observe/key } \\
\text { informant interviews }\end{array}$ & $\begin{array}{l}\text { Community leaders, } \\
\text { teachers, students }\end{array}$ & Once \\
\hline & Community organization & $x$ & & $\begin{array}{l}\text { Observe/key } \\
\text { informant interviews }\end{array}$ & $\begin{array}{l}\text { Community leaders, } \\
\text { teachers }\end{array}$ & Once \\
\hline & $\begin{array}{l}\text { Community facilities } \\
\text { and resources }\end{array}$ & $x$ & $x$ & $\begin{array}{l}\text { Community mapping } \\
\text { Wealth ranking }\end{array}$ & $\begin{array}{l}2 \text { groups of male comm. } \\
\text { members approx. } 20 \text { people }\end{array}$ & Twice \\
\hline & Hygiene and sanitation & $x$ & $x$ & $\begin{array}{l}\text { Observation, } \\
\text { Community mapping } \\
\text { \& Health walk }\end{array}$ & $\begin{array}{l}2 \text { groups of female comm. } \\
\text { members approx. } 20 \text { people }\end{array}$ & Twice \\
\hline & Disease periodicity & $x$ & $x$ & $\begin{array}{l}\text { Seasonal calendar } \\
\text { (focus group) }\end{array}$ & $\begin{array}{l}2 \text { groups of female comm. } \\
\text { members approx. } 20 \text { people }\end{array}$ & $\begin{array}{l}\text { Twice, summer and winter } \\
\text { recall periods }\end{array}$ \\
\hline & Historical information & $x$ & & $\begin{array}{l}\text { Timeline } \\
\text { (focus groups) }\end{array}$ & $\begin{array}{l}\text { Groups of 6-9 people } \\
\text { - elderly }\left(1^{\star}\right) \\
\text { - fishermen (2) } \\
\text { - hunters (2) } \\
\text { - farmers (2) } \\
\text { - women (3) }\end{array}$ & $\begin{array}{l}\text { Once, for entire history } \\
\text { of community }\end{array}$ \\
\hline \multirow[t]{5}{*}{ Individual } & Diarrhea management & $x$ & $x$ & $\begin{array}{l}\text { Key informant } \\
\text { interviews/case histories } \\
\text { and decision models }\end{array}$ & $\begin{array}{l}\text { Interviews with: } \\
\text { - } 8-10 \text { people knowledgeable } \\
\text { of health issues } \\
\text { - } 10 \text { women with children } \\
\text { with a recent diarrhea } \\
\text { episode }\end{array}$ & Twice, dry and wet season \\
\hline & $\begin{array}{l}\text { Nutritional ethnography } \\
\text { (local classification) }\end{array}$ & $x$ & & $\begin{array}{l}\text { Pile sort/food } \\
\text { attributes/attribute } \\
\text { rating }\end{array}$ & $\begin{array}{l}\text { Small groups of 2-3 people } \\
\text { include: } \\
\text { - women with children } \\
<5 \text { yrs. (5) } \\
\text { - women > } 45 \text { yrs (5) } \\
\text { - men (2) } \\
\text { - adolescents (2) } \\
\text { - teachers (2) }\end{array}$ & Once \\
\hline & Health ethnography & $x$ & & $\begin{array}{l}\text { Focus groups } \\
\text { Body and sexuality } \\
\text { mapping }\end{array}$ & $\begin{array}{l}\text { Focus groups include: } \\
\text { - women with children } \\
<5 \text { yrs (2) } \\
\text { - women > } 45 \text { yrs (2) } \\
\text { - men (1) } \\
\text { - adolescents (1) }\end{array}$ & Once \\
\hline & $\begin{array}{l}\text { Fertility (pregnancy, } \\
\text { prenatal care, birth, diet, } \\
\text { contraception etc.) }\end{array}$ & $x$ & & Interviews & $\begin{array}{l}\text { Interviews with } 10 \text { women } \\
\text { of different ages }\end{array}$ & Once \\
\hline & $\begin{array}{l}\text { Risk management } \\
\text { (identification of risks, } \\
\text { frequency, predictability } \\
\text { and coping strategies) }\end{array}$ & $x$ & $x$ & $\begin{array}{l}\text { Focus groups } \\
\text { Life histories }\end{array}$ & $\begin{array}{l}\text { Groups of 6-9 people } \\
\text { - elderly (1) } \\
\text { - fishermen (2) } \\
\text { - hunters (2) } \\
\text { - farmers (2) } \\
\text { - women (3) }\end{array}$ & $\begin{array}{l}\text { Twice (recall is to the } \\
\text { extent to which they can } \\
\text { remember) }\end{array}$ \\
\hline
\end{tabular}




\section{Community action plans}

Within each village Community Action Plans (CAPs) are being developed based on the research findings and local indicators of health. Together with the community, ecosystem management strategies are being identified that diversify diet, improve food security, and alleviate health problems.

\section{Application of the Ecosystem Approach}

International Development and Research Centre (IDRC's) Program Initiative, Ecosystem Approaches to Human Health, funds this project. Its goal is to improve human health by supporting trans-disciplinary research on the structure and function of stressed ecosystems on which people depend for their livelihoods and by applying this knowledge to the development of appropriate and effective interventions and policies. In the past two decades, CIAT's research agenda in the Peruvian Amazon has evolved from a single commodity focus (pastures, plantains, and rice) to more integrated natural resource management. In collaboration with the International Centre for Agroforestry Research (ICRAF) and the Centre for Forestry Research (CIFOR), CIAT is developing different land use options that promote economic development and reduce deforestation and land degradation. This study provides important methods and data to broaden this evaluation to include the health and nutritional issues and ultimately at the policy level to synchronize health and land use goals. This research builds on earlier conceptual work that proposed a research process for tropical ecosystems called AMESH, Adaptive Methodology for Ecosystem Sustainability and Health (Murray et al., in press).

In the development and application of the specific methodology, three key attributes of an ecosystem approach emerged that were deemed critical to its success. They included; (a) interdisciplinarity and methodological pluralism; (b) nested hierarchy and cross-scale interactions; and (c) participatory action research.

\section{Interdiscplinarity and methodological pluralism}

No complex socio-ecological system can be captured using a single model. They can be understood only from multiple, non-equivalent perspectives, as no single perception is able to provide a comprehensive or adequate view of reality (Checkland, 1981; Puccia \& Levins, 1985; Funtowicz \& Ravetz, 1994). Research on ecosystems therefore necessitates a variety of forms of inquiry, multiple sources of evidence, and dialogue with persons representing different worldviews (Checkland \& Scholes, 1990; Holling, 1995a; Waltner-Toews \& Wall, 1997). The goals of the system are therefore multiple, and tradeoffs are negotiated among stakeholders (Pretty, 1998; Woodhill \& Roling, 1998).

The ecosystem approach explicitly calls for a plurality of methods, drawing from several disciplines including both the "hard" and "soft" sciences. In the study, they ranged from GIS (Geographic Information Systems) analysis and landscape epidemiology to precise food recall techniques and participatory nutritional ethnography. Each method was selected based on how useful, appropriate, and effective it was at answering a particular question. Upon implementation, the method was evaluated in terms of the accuracy and reliability of the information it provided. This iterative process of methodological evaluation and modification was critical to the design of the study and the success of the results. For example, reliable information on morbidity and mortality failed to be captured by the individual surveys. Responses were simplified and restrained. However focus groups in a private place prompted active engagement in discussions. The recognition that others suffered similar illnesses was a catalyst that prompted further exploration of treatments and prevention measures. The leap from passive respondents to active participants allowed women to not only identify their problems, but to analyze their etiology and link their health to other factors in their environment. At the outset, quantitative data was sought, however, in reality the situation demanded a process through which local understanding could be generated. What was lacking, besides exact figures on morbidity was the creation of space or process through which women could better understand their problems and develop tools to do something about it.

This highlights the difference between "data" and "process" approaches, one more subtle and ultimately more useful than the familiar quantitative versus qualitative or social versus natural science distinction. Data and process approaches should be used simultaneously. Recognizing that data and process approaches tap different information sources and produce different outputs, the critical issue is how to combine them as complementary methods. That is, the challenge comes in not only col- 
lecting reliable and accurate data, but rather in seeing how the actual process of gathering information initiates other processes and changes existing processes within the community itself.

Considering a plurality of methodologies, the sequence in which different methods are implemented affects one's ability to compensate for weaknesses in individual techniques and to build on knowledge systematically. Different methods can be used to verify and crosscheck information. The more qualitative participatory methods in the study provided insight into those health issues that the community perceived as important. The extensive survey then helped determine the extent to which these health problems affect the whole community and which groups were most at risk. Moreover, once the community was involved in focus groups and felt that their needs were driving the project, they were more responsive and interested in the survey. They were better able to appreciate its value and therefore were more motivated to provide accurate answers.

\section{Multiple scales in time and space}

Ecosystems exist within nested hierarchies or holarchies (Checkland \& Scholes, 1990; Allen \& Hoekstra, 1992). They are comprised of smaller systems while at the same time being part of a larger whole. A household is therefore part of a community, while similarly being made up of different individuals. The different layers (household, community, region, and nation) evolve within a variety of ecological and socioeconomic contexts and constraints (Allen \& Starr, 1982; Allen et al., 1993; Conway, 1987). Complexity emerges when the speed of change of a variable at one scale affects variables at other scales. Therefore the essential properties of the parts of a system can only be understood from the organization of the whole (Bertalanffy, 1968; Capra, 1996) and the interaction of variables across different scales. As opposed to linear causality, positive and negative feedback loops and discontinuity describe the nature of the relationships and patterns of system behavior (Kay \& Schneider, 1992; Holling, 1995b; Ulanowicz, 1997). Such properties limit our capacity to predict how the situation will unfold (Prigogine \& Stengers, 1984) and create a high level of uncertainty in management and policy (Holling, 1986).

As evident in Table 1 and 2 , the study variables exist at several scales, from the individual through to the landscape. Differences in nutrient intake of individuals versus families provide insight into issues of intra-household food allocation. Food security at the community versus the landscape level highlights the importance of surrounding ecological resources and biodiversity as food sources. The investigation of food and income sources at the farm, community, and landscape level exposed the finding that the majority of families depend on an area much larger than their farm for their livelihood. Despite issues of access, the rural population is constantly moving, synchronized to the rising and falling of rivers and lakes and the migratory paths of fish and animals. This continuous flow of people and resources sustains their livelihoods, as rarely can the area immediately surrounding them provide adequately for their needs. This extensive resource use system that dominates the region has important implications for land use options that attempt to intensify and concentrate resource use. Research and development activities confined to the farm or even the community fail to capture the complete picture of the livelihood strategies in Ucayali and the link between activities at different scales.

In addition to spatial differences, multiple temporal scales are equally important in understanding ecosystem dynamics and its relationship to health. Each variable in the study had a temporal dimension. Three time periods were selected to reflect seasonal changes, emphasizing the patterns of change of these different variables over the year and the interactions among such changes. Therefore the nature of the links between the hydrological cycle, fluctuations in disease prevalence, and changes in nutrient intake can provide insight into the determinants of health and the causal linkages between the components.

\section{Participatory action research}

"Participatory action research (PAR) is not just research that we hope will be followed by action, it is action which is researched, changed, and reresearched within the research process by the participants. Change does not happen at "the end" - it happens throughout" (Wadsworth, 1998:9).

Sustainable natural resource use is not a simple model or package to be imposed; it is more accurately described as a "process for learning" (Pretty, 1998). The shift to greater ecosystem sustainability and health involves not only the identification of appropriate resource uses, but learning those practices, facilitating that learning, and creating institutional and policy frameworks that support such facil- 
itation (Woodhill \& Roling, 1998). This requires legitimate involvement of the local community, be they government agencies, women's groups, nongovernmental organizations (NGOs), or the community members themselves.

Active local participation is fundamental to the ecosystem approach. Without their involvement, researchers cannot address the different conflicting goals whose interaction and trade-off affect overall sustainability and health of the ecosystem. In the study, a larger research team was created comprised of representatives from relevant organizations. In this larger group, project objectives were refined and methods developed. More importantly, five of the twelve researchers involved in the field work were leaders or professionals from local governmental and nongovernmental organizations. This ensured that knowledge in the methods as well as research findings fed back into local institutions and enhanced a sense of local ownership of the data and their implications.

The action component of PAR is equally important in the ecosystem approach. At the outset it was assumed that the process from analysis to action would be completed through once. First, with the participation of the local community the problem(s) would be diagnosed, then fieldwork implemented, community plans generated from the "answers", new actions put into practice, and lastly the results evaluated. In reality, there was not one path from participation to research to action; instead, countless smaller cycles of participatory reflection on action, learning about action, and new informed action, all of which fed back on one another. After six months in the field, several small-scale plans have been developed, simple actions carried out, and these experiences used to focus and refine the understanding of what is really happening and what is really important to the community.

The key question is thus how much diagnosis and analysis is needed before action is taken. In contrast to the longer, more conventional route of data collection and analysis, followed often years later with policy recommendations or development projects, in this study, researchers engaged in shorter cycles, whereby questions were raised, hypotheses tested, plans generated from the answers found, and new actions/projects employed. This process was then immediately evaluated. If successful, it was expanded upon, if unsuccessful, hypotheses were re-visited, methods adapted, and the necessary fieldwork carried out. This cycle occurs several times within the life of the project, each time re-focusing and expanding under- standing of the problem and its appropriate solutions.

Application of this adaptive and iterative research cycle led to the discovery that there were in reality several cycles existing simultaneously, however moving at different speeds. It was evident that the more complex research questions required a longer cycle, where rigor in methods and analysis demanded years of work. For example, seasonality of nutritional status and disease periodicity required at least a year of research and similar data from communities located in different ecosystems.

However, other questions that require smaller time intervals between analysis and action were critical in involving the community early on in the study. Water quality, parasite loading, and anemia tests provided a good starting point, as these tests were conducted in the field and findings were readily available. The community was quickly able to grasp the significance of the results and incorporate them into their understanding of larger health issues. In several communities, stool and water testing initiated immediate action in cleaning and controlling defecation along stream banks and reducing contamination of wells. With time and the community's growing understanding of their health problems, results from more complex issues such as the linkages between anthropogenic environmental change and disease transmission become more accessible. In addition, this early emphasis on action promoted greater interest and local ownership of the information, findings, and solutions. Ultimately, researchers are agents of change, recognizing and acknowledging their role as catalysts in the community.

Lastly, participatory research must address the fact that communities are rarely homogenous in their composition and concerns. Differences in interests and conflicts within the community shed light on power relations and structures. Although gender is the obvious starting point, particularly with respect to health, it is not the only difference, nor is it always the main difference that affects people's decisions and options. Qualifying the category of women into smaller groups of older, poorer, or minority, shows that in some settings their identification as "women" may be less important than their relative wealth, level of education, or age (Cornwall, 1999). Differences between men and women are not fixed; often they emerge and become significant in different ways and in different contexts. 


\section{Conclusion}

An ecosystem approach to human health assessment provides an inter-disciplinary, holistic view of the socioeconomic and ecological factors affecting health. Research focuses on the relationships between the structure and function of stressed ecosystems and land use strategies, between natural resource use and nutritional status and between anthropogenic environmental changes and the transmission dynamics of disease. Capturing the complexity of these causal linkages and feedback demands a plurality of methods, multiple scales of investigation and active local participation.

\section{References}

AKANJI, K., 1998. Income changes and nutritional status. Gender CG Newsletter, 1:4-6.

ALLEN, T. \& HOEKSTRA, T. W., 1992. Toward a Unified Ecology. New York: Columbia University Press.

ALLEN, T. F.; KING, A. W.; MILNE, B.; JOHNSON, A. \& TURNER, S., 1993. The problem of scaling. Evolutionary Trends in Plants, 7:3-8.

ALLEN, T. F. \& STARR, T. B., 1982. Hierarchy: Perspectives for Ecological Complexity. Chicago: University of Chicago Press.

BAILEY, K.; DE ONIS, M. \& BLOSSNER, P., 1998. Protein-energy malnutrition. In: Malnutrition and the Burden of Disease: The Global Epidemiology of Protein-energy Malnutrition, Anaemias and Vitamin Deficiencies (C. Murray \& A. Lopez, eds.), pp. 75-89, Cambridge: The Global Burden of Disease and Injury Series.

BEHRMAN, J. R., 1995. Household Behaviours and Micronutrients: What We Know and don't Know. Working Papers on Agricultural Strategies for Micronutrients, No. 2. Washington, D.C.: IFPRI.

BEHRMAN, J. R. \& DEOLALIKAR, A., 1987. Will developing country nutrition improve with income? A case study for rural south India. Journal of Political Economy, 95:108-138.

BERTALANFFY, L., 1968. General Systems Theory. New York: Braziller.

CAPRA, F., 1996. The Web of Life. New York: Anchor Books.
CHECKLAND, P., 1981. Systems Thinking, Systems Practice. Chichester: John Wiley \& Sons.

CHECKLAND, P. \& SCHOLES, P., 1990. Soft Systems Methodology in Action. Chichester: John Wiley \& Sons.

CONWAY, G. R., 1987. The properties of agroecosystems. Agricultural Systems, 24:95-117.

CORNWALL, K., 1999. Gender and development. In: Myth of the Community (I. Gijt, ed.), pp. 135-156, London: Intermediate Technology Development Group.

DIRECCION REGIONAL DE SALUD, DIRECCION DE ESTADISTICAS E INFORMACION, 1997. Informe Anual de Salud: Ucayali 1997. Lima: Dirección Regional de Salud, Dirección de Estadísticas e Información.

FUNTOWICZ, S. \& RAVETZ, J., 1994. Emergent complex systems. Futures, 26:568-582.

HOLLING, C. S., 1986. Resilience of ecosystems. Local surprise and global change. In: Sustainable Development of the Biosphere (W. Clark \& R. Munn, eds.), pp. 45-59, Cambridge: Cambridge University Press.

HOLLING, C. S., 1995a. What barriers? What bridges? In: Barriers and Bridges to the Renewal of Ecosystems and Institutions (L. H. Gunderson, C. S. Holling \& S. S. Light, eds.), pp. 356-378, New York: Columbia Press.

HOLLING, C. S., 1995b. Sustainability: The crossscale dimension. In: Defining and Measuring 
Sustainability: The Biogeophysical Foundations (M. Munasinghe \& W. Shearer, eds.), pp. 245-265, New York: The United Nations University/World Bank.

INEI (Instituto Nacional de Estadísticas y Informática), 1997a. Población. Mujer y Salud. Resultados de la Encuesta Demográfica y de Salud Familiar. Lima: INEI.

INEI (Instituto Nacional de Estadísticas y Informática), 1997b. Ucayali: Estadísticas del Medio Ambiente 1996-97. Pucallpa: INEI.

IUCN (International Union of the Conservation of Nature), 1996. The Conservation Atlas of Tropical Forests: The Americas (C. S. Harcourt \& J. A. Sayer, eds.), New York: Simon and Schuster.

KAY, J. J. \& SCHNEIDER, E., 1992. Thermodynamics and measures of ecosystem integrity. In: Ecological Indicators: Proceedings of the International Symposium on Ecological Indicators (M. McKenzie, D. Hyatt \& J. McDonald, eds.), pp. 159-181, New York: Elsevier.

KINSEY, P., 1998. Cash cropping and nutritional status. Gender CG Newsletter, 1:8-10.

LEONARD, W.; DEWALT, K.; UQUILLAS, J. \& DEWALT, B., 1993. Ecological correlates of dietary consumption and nutritional status in coastal Ecuador. Ecology of Food and Nutrition, 31:67-85.

MURRAY, T.; KAY, J.; WALTNER-TOEWS, D. \& RAEZLUNA, E. Adaptive methodology for ecosystem sustainability and health (AMESH): An introduction. In: Conservation Medicine (G. Tabor et al., eds.), Boston: Tufts University. (in press)

NOWAK, K., 1998. Commercial crops and changes in child health. Gender CG Newsletter, 1:16-19.

PRETTY, J. N., 1998. Supporting policies and practice for scaling up sustainable agriculture. In: Facilitating Sustainable Agriculture: Participatory Learning and Adaptive Management in Times of Environmental Uncertainty (N. G. Roling \& M. A. Wagemakers, eds.), pp. 23-45, Cambridge: Cambridge University Press.
PRIGOGINE, I. \& STENGERS, I., 1984. Order out of Chaos: Man's New Dialogue with Nature. New York: Bantam

PELLETIER, D.; FRONGILLO, E. \& HABICHT, J., 1993. Epidemiologic potentiating effect of malnutrition on child mortality. American Journal of Public Health, 83:1130-1133.

PUCCIA, C. J. \& LEVINS, R., 1985. Qualitative Modeling of Complex Systems. Cambridge: Harvard University Press.

ULANOWICZ, R. E., 1997. Ecology: The Ascendent Perspective. New York: Columbia University Press.

VON BRAUN, J. \& KENNEDY, E., 1994. Agricultural Commercialization, Economic Development and Nutrition. Baltimore: Johns Hopkins Press for IFPRI.

WADSWORTH, Y., 1998. What is Participatory Action Research? Action Research International, Paper 2. <http://www.scu.edu.au/schools/sawd/ari/ariwadsworth.html>.

WALTNER-TOEWS, D. \& WALL, E., 1997. Emergent perplexity: In search of post-normal questions for agroecosystem health. Social Science and Medicine, 45:1741-1749.

WOODHILL, J. \& ROLING, N., 1998. The second wing of the eagle. In: Facilitating Sustainable Agriculture: Participatory Learning and Adaptive Management in Times of Environmental Uncertainty (N. G. Roling \& M. A. Wagemakers, eds.), pp. 4672, Cambridge: Cambridge University Press.

WORLD BANK, 1980. World Development Report, 1980. Washington, D.C.: World Bank. 